\title{
Family Health Conversations Versus Support Group Conversations When a Family Member Has Been Critically III: A Mixed Methods Study
}

Mona Ahlberg, Carina Persson, Carina Berterö and Susanna Ågren

The self-archived postprint version of this journal article is available at Linköping University Institutional Repository (DiVA):

$\underline{\text { http://urn.kb.se/resolve?urn=urn:nbn:se:liu:diva-178966 }}$

N.B.: When citing this work, cite the original publication.

Ahlberg, M., Persson, C., Berterö, C., Ågren, S., (2021), Family Health Conversations Versus Support Group Conversations When a Family Member Has Been Critically Ill: A Mixed Methods Study,

Families, Systems \& Health, 39(2), 293-305. https://doi.org/10.1037/fshoooo6o7

Original publication available at:

https://doi.org/10.1037/fshooo0607

Copyright: American Psychological Association

http://www.apa.org/ 
Family health conversations versus support group conversations when a family member has been critically ill. A mixed method study.

Mona Ahlberg ${ }^{\mathrm{a},}$, Carina Persson ${ }^{\mathrm{b}}$, Carina Berterö ${ }^{\mathrm{c}}$ and Susanna Ågren ${ }^{\mathrm{d}}$

${ }^{\text {a }}$ Department of Anesthesiology and Intensive Care, and Department of Medical and Health Sciences, Linköping University, Norrköping, Sweden.

${ }^{\mathrm{b}}$ Department of Health and Caring Sciences, Linnaeus University, Kalmar, Sweden.

${ }^{c}$ Department of Medical and Health Sciences, Linköping University, Linköping, Sweden.

${ }^{\mathrm{d}}$ Department of Cardiothoracic Surgery and Department of Medical and Health Sciences, Linköping University, Sweden.

mona.k.ahlberg@regionostergotland.se; carina.persson@lnu.se ;

carina.bertero@liu.se; susanna.agren@liu.se

Corresponding author: Mona Ahlberg mona.k.ahlberg@,regionostergotland.se

\section{Funding}

The present study was supported, in part, by grants from the Health Research Council in the South-east of Sweden (FORSS 466311), as well as from the Department of Anesthesiology and Intensive Care, Norrköping, Sweden and the Department of Medical and Health Sciences, Linköping University, Linköping, Sweden.

\section{Acknowledgments}

The authors wish to extend their appreciation to the families experiencing critical illness and intensive care who generously shared their experiences with us. They also acknowledge the 
help and collaboration of the statistician and Senior Lecturer Mats Fredriksson at Forum Östergötland, Linköping University.

\section{Declaration of conflicting interests}

The authors declare no potential conflicts of interest with respect to the research, authorship, and/or publication of this article.

\section{ORCID iD}

Mona Ahlberg (iD https://orcid.org/0000-0001-5132-0045

Carina Persson iD https://orcid.org/0000-0002-1876-213X

Carina Berterö (D) https://orcid.org/0000-0003-1588-135x

Susanna Ågren (iD https://orcid.org/0000-0002-3178-3592 


\section{Abstract}

Introduction: When a family member has been critically ill and cared for at an intensive care unit the individual family member as well as the family system are affected and in need of support. The aim of this study was to compare and contrast the responses from two different types of follow-up interventions for families of critically ill persons, focusing on individual hopes, health-related quality of life, family functioning and ability to cope with challenges. Methods: Adult family members from three hospitals attended one of two interventions two months after intensive care. The family health conversation included the family. The support group conversation included just family members and not the patient who had experienced intensive care. Data were collected via self-reported questionnaires and follow-up interviews with family members. Quantitative and qualitative data were first analyzed separately, and the results were then integrated through mixed methods analysis. Results: A total of 38 family members took part in the interventions. Family members in the two intervention groups talked about how they had more hope for the future, and about how talking within the family and the group had helped them justify their feelings, which empowered them in the transition toward a healthier quality of life. Comparisons of the interventions show a higher significance of family function and hope in the family health conversation. Discussion: The article illustrates a disparity between how family members function and the needs they have for follow-up. We discuss what kind of follow-up these persons need.

Keywords: Family members, Family nursing, Family relations, Intensive care, Mixed methods 


\section{Introduction}

Family members experiencing critical illness and intensive care (ICU) may lose hope and have reduced health-related quality of life (Griffith et al., 2018; Alfheim et al., 2019;

Orwelius, Kristenson, Fredrikson, Walther, \& Sjöberg, 2017a; Heyland et al., 2018). Past studies have found that for family members of critically ill ICU patients, the prevalence of anxiety was 15 - 24\%, depression was 4.7-36.4\%, and PTSD was 35- 57.1\% six months after ICU discharge (van Beusekom, Bakhshi-Raiez, de Keizer, Dongelmans \& van der Schaaf, 2016). From a system level perspective, the family may find it difficult to function or to cope with challenges, such as reduced family well-being and family function, high stress, and low mental health (Agren, Eriksson, Fredrikson, Hollman Frisman, \& Orwelius, 2019; Alfheim et al., 2019; Kynoch, Chang, Coyer, \& McArdle, 2016). This implies a need for follow-up for families with a family member who has been cared for in the ICU.

There is international consensus concerning the need for ICU follow-up, although there is no consensus on the best model (Jonasdottir, Jones, Sigurdsson, \& Jonsdottir, 2018; Rosa et al., 2019). Countries have different approaches to follow-up after ICU, and on whether to involve family members who visit the patient (Jonasdottir, Klinke, \& Jonsdottir, 2016). Some ICUs give family members the opportunity to talk to a medical social worker, while others have open-session meetings for families (Lasiter, Oles, Mundell, London, \& Khan, 2016; Peskett \& Gibb, 2009). In Sweden, the main purpose of follow-up clinics is to give the ICU patient information, and to follow up on the patient's experiences and well-being (SIR, 2020). Sometimes the former ICU patient is too ill to attend the follow-up clinic or does not consider it necessary. Research shows that family members could still benefit from follow-up (Ahlberg, Backman, Jones, Walther, \& Hollman Frisman, 2015; Vandall-Walker \& Clark, 2011). A study made in the ICU with family function outcomes shows that the intervention known as the family health conversation; a family nurse lead conversation, improves family 
well-being by improving family function, reducing stress, and promoting better mental health (Agren, Eriksson, Fredrikson, Hollman Frisman, \& Orwelius, 2019). The family health conversation has also been used and evaluated in families at a residential home (Dorell, Isaksson, Östlund, \& Sundin, 2017), and by families living with various chronic diseases (Benzein, Olin, \& Persson, 2015; Sundin et al., 2016; Östlund, Bäckström, Saveman, Lindh, $\&$ Sundin, 2016). Overall using these interventions show positive health-related outcomes for family well-being and functioning.

We are interested in whether support to family members, excluding the patient, in the support group conversations is equivalent to support offered to the family, including the patient, in the family health conversation in terms of individual outcomes and family system outcomes. Family health conversations that support the family members of critically ill patients, have previously been shown to put the family system in focus, when identifying and resolving issues that affect family functioning (Ahlberg, Hollman Frisman, Berterö, \& Ågren, 2020). Support group communication has been shown to facilitate the process of shouldering the burden of being a partner of an intensive care patient (Ahlberg et al., 2015). Using the concepts and measurements of hope, health-related quality of life, family functioning and ability to cope with challenges we hope to capture the importance of follow-up with familyfocused care. Therefore, the aim of this study was to compare and contrast the responses from two different types of follow-up interventions for families of critically ill persons, focusing on individual hopes, health-related quality of life, family functioning and ability to cope with challenges. 


\section{Methods}

\section{Design}

A mixed methods study design (Creswell, 2014; Tashakkori \& Teddlie, 2010) including data from interviews and questionnaires, was used to explore and compare the two interventions: Family health Conversations (FamHC) and Support group Conversations (SGC). Each type of data was first analyzed separately and then integrated at the interpretation and reporting level by means of mixed methods analysis (Fetters, Curry, \& Creswell, 2013).

\section{Participants}

Two different general ICUs were involved in the FamHC intervention: one regional hospital and one university hospital in Sweden. The participants in the SGC intervention had experience of another general ICU in a regional hospital. There was only one intervention ongoing during this time. The timeframe was first the FamHC intervention and after that the SGC intervention.

Former critically ill patients and their family members were consecutively recruited to the interventions. Nurses working at the ICU follow up clinic called the participants. Eligible ICU patients received a mail request to participate two months after their ICU care and indicated which family members could be asked to participate. Family members were defined as anyone the patient considered as belonging to the family (Whall, 1986). The criteria for inclusion in the two interventions were being cared for in the ICU for $\geq 72$ hours and $\geq 18$ years old or being a family member $\geq 18$ years old.

The Ethics Review Board in Linköping approved the study (record no. 2013/228-31, 2015/367-31, 2016/292-32, 2017/164-32, and 2018/572-32). Written informed consent was obtained from all family members, and the research was carried out in line with the 
Declaration of Helsinki (WMA, 2013). Data was coded, saved, and stored under current rules to prevent personal identification (Regulation (EU) 2016/679).

\section{Interventions}

The theoretical background of the two interventions was the Calgary Family Assessment and Intervention Model (Wright \& Leahey, 2013), and particularly the Illness Beliefs Model (Wright \& Bell, 2009), which is theoretically based on constructivism, cybernetics, and system, communication and change theory (Wright \& Leahey, 2013). Both interventions are framed within family-focused care which can be described in two ways; family-centered and family-related. (Benzein, Hagberg, \& Saveman, 2008; Wright \& Bell, 2009; Wright \& Leahey, 2013). The interventions are focused on relational patterns/family interaction patterns, but the FamHC takes the family's perspective, while the SGC takes its starting point from individual family members' perspectives on these patterns.

The FamHC model has been culturally adapted to Swedish conditions (Benzein, Hagberg, \& Saveman, 2008). The conversations focus on the family's resources and acknowledge the experiences and perspectives of each participating family member. Each person is invited to tell their story and listen to the stories of the other family members. The reflective questions the nurses ask encourage alternative ways of thinking about the family's situation and their ability to cope with challenges. This helps the family function more effectively (Benzein et al., 2008) (see Figure 1).

The SGC intervention involves members from different families, excluding the patients cared for in the ICU. The purpose of SGCs is for family members to get together to talk about, and listen to, what family members from various families have felt and experienced in relation to having had a critically ill family member in the ICU. The conversation focused on 
the family experiencing the critical illness, but the patients' experiences were not requested. (see Figure 1).

Four ICU nurses working at the ICU follow-up clinic, with university training in FamHC, performed the interventions FamHC and SGC.

\section{Data collection}

Data was collected at base line (questionnaires) and at three months post-intervention (interviews and questionnaires) (Figure 2).

\section{Follow-up interviews}

Participants were contacted by telephone to schedule the interviews. The four interviewers were female, had long experience, and were well trained in research interviewing. They had not been involved in the allocation of the groups, the interventions or in the ICU care. The interviewer knew during the interview which intervention the participant/participants had attended.

Use of a semi-structured interview guide (Kallio, Pietilä, Johnson \& Kangasniemi, 2016), developed by the research team and the interviewers contributes to the trustworthiness of the qualitative research method. The interview guide comprised open-ended questions focusing on family members' experiences of the interventions. The starting question was: Would you please tell me how you experienced the intervention? The families were then asked to describe the significance of the conversations for family well-being, family functioning and individual experiences of stress and hope. Probing questions were used to further explore the participants' various experiences. Family interviews (Eggenberger \& Nelms, 2007) were performed in the families' homes with the families that had participated in the FamHC intervention. The family members in the SGC intervention were interviewed individually; one interview was conducted in a consultation room at the hospital, two by telephone and 15 
through video calls. The interviews varied between six and 60 minutes and the mean length was 25 minutes (family interviews) and 15 minutes (individual interviews).

\section{Questionnaires}

The questionnaires were individually scored, regardless of focus level (individual or family/systems). The mode of administration was through letters sent by mail to the participants, with a prepaid addressed envelope to return. Background data were collected using a self-administered questionnaire which asked about sex, age, employment, and the patient's stay in the ICU.

The General Functioning Scale (GFS) was used to measure overall family functioning. The GFS is a sub-scale within the Family Assessment Device, FAD, and measures interactions within the family (Epstein, Baldwin, \& Bishop, 1983). It is a summative scale with 12 items, where the total score is the mean of all items, ranging from 1 to 4 . Scores $<2$ indicate that family functioning is good. The reliability of the Swedish version has shown an ordinal alpha value of 0.92, (Bylund, Arestedt, Benzein, Thorell, \& Persson, 2016).

The Family Sense of Coherence Scale (FSOC-S) assesses the extent to which the world is seen as comprehensible, manageable, and meaningful, focusing on the family to manage the new situation. The FSOC-S consists of 12 questions. The highest score is 12, with a cut-off score of 4, where a higher score indicates a stronger sense of coherence (Antonovsky \& Sourani, 1988). Reliability testing of the Swedish version has shown an alpha value of 0.91 (Mollerberg, Arestedt, Sandgren, Benzein, \& Swahnberg, 2020).

The Herth Hope Index (HHI) measures hope on an individual level (Herth, 1992). The HHI has 12 items using a four-point Likert scale. The highest score (range 12-48), indicates high levels of hope. The reliability of the Swedish version (S-HHI) has shown an alpha value of 0.88 (Benzein \& Berg, 2003). 
The Research and Development (RAND-36) and the Medical Outcome Short-Form health survey (SF-36) are two equivalent scales assessing the health-related quality of life of the individual. The scales assess eight health concepts on a multi-item scale with 35 items. An additional, single item assesses change in perceived health during the last 12 months. Scores range from 0 to 100, where higher scores indicate better health-related quality of life (Hays \& Morales, 2001; Stewart \& Ware, 1992). The SF-36 was used in the FamHC intervention and the RAND -36 was used in the SGC intervention. RAND-36 is used for entering ICU patients into the Swedish Intensive Care Register, which previously used the Medical Outcome ShortForm health survey (SF-36). Both questionnaires were used in this study, and they can be analyzed together, as we collected data during different years (SIR, 2020). The Swedishlanguage version of the RAND-36 has been validated and has a reliability of $\alpha 0.86-0.97$ (Orwelius et al., 2017b).

\section{Data analysis}

\section{Statistics}

The questionnaire data were coded and entered into the Statistical Package for the Social Sciences version 25 .

Univariate methods were used to describe the sample. An independent t-test, or one-way ANOVA, was used to compare background variables within the two intervention groups. The patients were removed from the final analysis to enable the data to be compared between interventions. The base 10 logarithm function was used for normally distributed data because of intra-family correlations (Altman, 1991). The difference between three months and baseline was calculated and then analyzed using the linear mixed-effects model to adjust for the covariance structure of the data (Field, 2013). The level for statistical significance was set at $\mathrm{p}<0.05$. A statistician was involved in the data analysis (MF). 


\section{Qualitative analysis}

The transcribed follow-up interviews from the SGC and FamHC interventions were analyzed separately using narrative analysis (Lieblich, Tuval-Mashiach, \& Zilber, 1998). The analysis had five components (see Fig. 3). The transcribed interviews were repeatedly read, summarized, and analyzed separately by the authors. The authors discussed their analyses until consensus was reached (Lieblich et al., 1998).

\section{Mixed methods analysis}

The quantitative and qualitative results were integrated using mixed methods and are shown according to the purpose of introjections between methods: recasting the results of qualitative narrative analysis in the FamHC with quantitative results, looking for contradictions and/or new perspectives. The results from the SGC data were analyzed in the same way. The total results from the FamHC data were then cross-validated with those from the SGC data (Greene, Caracelli, \& Graham, 1989; Tashakkori \& Teddlie, 2010) (see Figure 4).

\section{Results}

\section{Participant characteristics}

A total of 38 family members, took part in the SGC intervention. Seventeen members of seven families participated in the FamHC intervention (including the patient), and 21 members of 13 families (excluding the patient). There was a statistically significant difference $(p=.028)$ in ICU stay of the two intervention groups: the mean stay in the FamHC intervention group was eight days while in the SGC intervention group it was 13 days. More females in the FamHC and more participants in this group were unemployed or were receiving a pension. (Fig. $1 \& 2$ : Table 1 ). 


\section{Findings concerning the FamHC intervention}

The findings from the follow-up family interviews indicated that families functioned better than before the intervention. When they talked and listened to each other, they noted differences in their experience of the illness, including how they viewed the ICU stay. By making these differences visible, a greater understanding developed within the family. These results were validated in the GFS questionnaire assessments, showing that families functioned better after the intervention $(p=0.042)$ (GFS, Table 2).

Families' experience of being able to talk about different issues regarding the ICU stay, and how these had affected them, changed within family talk, as did the way they talked with others about their feelings. This change in communication patterns can be linked to results from the quantitative analysis of the social functioning sub-scale (SF36) showing an increase in family members' ability to function socially ( $p=0.049)$ (SF36/SF, Table 2).

The families stated that they were doing their best to manage the new situation together, as a family. This experience of support and concern can probably be associated with the statistically significant improvement $(p=0.040)$ in family members' mental health $(\mathrm{SF} 36 / \mathrm{MH}$, Table 2).

\section{Findings concerning the SGC intervention}

The family members who took part in the SGC group felt more empowered by exchanging experiences of critical illness. Hearing about and reflecting on how other family members had made their everyday life work made it easier to understand how their own family could also cope. The perceived consequences for family life, and successful management of family stress associated with family coherence, were validated in the statistically significant positive values of scores in the FSOC-S total, $(p=0.001)$, the FSOC-S comprehensibility sub-scale $(p=0.033)$ and the FSOC-S meaningfulness sub-scale $(p=0.001)$ (Table 2$)$. 
Family members acknowledged that they played an important role in the recovery of the critically ill member of the family by developing a better understanding of their own and others' ongoing transition from critical illness. The strength of the family members' new perspectives was confirmed by increased meaningfulness $(p=0.001)$ in the FSOC-S over time and for the individual outcome "vitality" $(p=0.012)$ in RAND (Table 2$)$. This could indicate that family members had more energy and were more active.

Participants in the SGC intervention talked about how they were affected and how they now took their own life and health-related quality of life more seriously. The analysis of the GFS scores showed a significant difference $(p=0.000)$ between baseline and three months, indicating that family functioning was worse at follow-up, and below the cut-off for unhealthy functioning (Table 2).

Hope scored individually by the S-HHI questionnaire showed a significant $(p=0.002)$ decline over time. Also, the RAND scores for ability to function physically $(p=0.006)$ and socially $(p=0.001)$ were significantly reduced over time (Table 2 ).

\section{Comparison of the FamHC and SGC interventions}

The family ability to function differed among the intervention groups $(p=0.001)$ (Table 2$)$, and the triangulation shows that a family's ability to function improved in the FamHC intervention and decreased in the SGC intervention.

The follow-up interviews illustrated that participants talked about how the FamHC intervention had influenced the family: "The conversations require the attention of the whole family and everyone is allowed to be heard, without anything said being branded strange or deviant." (FamHC 7). However, the SGC follow-up interview indicated that family members talked about how the intervention had influenced them as individuals: "The conversations gave me the opportunity to get a perspective on what I experienced, as well as the problems 
that might arise with her, because she hadn't seen or understood everything. And just the opportunity to take a step back and look a bit at my process and reflect on it in terms of the others' experiences" (SGC 17).

Differences in levels of hopefulness between the intervention groups were also significant $(p=0.016)$, where triangulation showed that hope increased in the FamHC intervention and decreased in the SGC intervention. A family member in the FamHC group said in a follow-up interview: "It opened you up to things you were 'hiding from', things you didn't really know how to confront or bring up. The conversations helped us family members talk about these things without them getting out of proportion" (FamHC 3). A family member in the SGC intervention mentioned the following: "Sometimes you are so full of your own thoughts and feelings, and you're having a hard time yourself, so it's difficult to take in how others feel, and even if we talk, you still have very strong feelings of despair" (SGC 19).

Family members in both the SGC and FamHC interventions talked about having their feelings endorsed, and described a sense of how they as individuals or as a family had felt accepted in their feelings. The follow-up interview in the FamHC group indicated that family members showed more concern for each other and felt the family had become more communicative: "The talks give the individual family members insight into how the others in the family experienced this incident with someone being seriously ill and being cared for in the intensive care unit. You relate your experiences and get to listen to how others experienced the same thing but in a completely different way." (FamHC 6). A family member in the SGC intervention gave the following comment: "It's so nice to hear that there is life on the other side. In other words, it will be better and it ... that you can see the light at the end of the tunnel and can enjoy the time and the days that remain" (SGC 22). 
None of the measures in SF36/RAND or FSOC-S showed a significant difference between the intervention groups.

\section{Discussion}

The findings showed that the two interventions differed in their responses, where the FamHC intervention mainly increased interactional aspects and individual hope while the SGC intervention increased family members' sense of family coherence and individual vitality.

Analysis of the questionnaires and follow-up interviews showed that families functioned better after FamHCs. This could only be speculated about; it could be because they had discussed their experiences together in the FamHC. They had shared and developed an understanding of the life worlds within the family. Another study involving parents of children in the ICU shows the importance of follow-up for increasing family functioning (Nelson, Lachman, Li, \& Gold, 2019).

Family members' mental health and ability to function socially might also have improved because they had discussed their feelings within the family. Family members were thus better able to tell others about their experiences and discover how the others within the family felt. This assumption is supported in findings from a qualitative study with follow-up interviews after FamHCs (Ahlberg et al., 2020).

Family members' assessed hope showed a decrease three months after taking part in SGCs. There was deterioration in health-related quality of life, defined as the ability to function physically and socially, which may also help to explain the decrease in hope found in this group. This is an important lesson to follow up, as is the fact that family members, as well as 
the critically ill patient in the family, could find follow-up useful. Family support groups were shown to provide a supportive environment, mutuality, and a sense of belonging, and met needs for community, unconditional acceptance, and information provision for the participants (Kirshbaum-Moriah, Harel, \& Benbenishty, 2018).

Although the findings of the follow-up interviews showed a deterioration in levels of hope, family members nevertheless talked about how hopeful they had become by talking and listening to others with similar experiences. They felt renewed, knowing that others had the same feelings, had gone through almost the same experience and were now living with good relationships within the family. The quantitative and qualitative data collection was carried out at the same time, but perhaps the scale HHI operationalizes hope in a different way to that described by the informants in the interviews. In a qualitative study with family members who had sat with a traumatic coma patient, hope was the most prominent theme, and was found to fluctuate (Verhaeghe, van Zuuren, Defloor, Duijnstee, \& Grypdonck, 2007).

Why do the two interventions differ? There are several possible ways to explain the difference. Firstly, in the FamHC group the family talked and listened to each other, whereas in the SGC study, the participants only talked to members of different families. In the SGC group, family members had the chance to talk to other families and hear about their experiences, but they did not have the opportunity to hear responses within their own family. There are incentives to continue to explore ways in which related aid will be offered in order to benefit former ICU patients and their families. Conversations with others are not detrimental to the family, but it is important to note that each family member has different needs. The critically ill patient in the family may not wish to talk about the critical illness, or may not be able to, because of their illness and/or mental health (Anderson, Arnold, Angus, \& Bryce, 2008; Bolosi et al., 2018). A Cochrane review looked at differences between types of ICU follow-up but found insufficient studies to be able to assess the differences and 
recommended further investigation (Schofield-Robinson, Lewis, Smith, McPeake, \& Alderson, 2018).

Another second source of difference may involve the fact that follow-up interviews in the FamHC group took place with the whole family, but only involved individuals in the SGC intervention. A family's ability to function is hard to determine by asking only one family member, even if families sometimes express their views more openly on this subject in individual settings (Astedt-Kurki, Paavilainen, \& Lehti, 2001). The time difference and different forms of interview may also contribute to different outcomes (Jack, 2008).

Time differences in the interventions may also be a reason for different outcomes. Perhaps the SGC participants would have yielded the same results as the FamHC group if they had had the opportunity to attend three conversation-group meetings. The time differences in terms of data collection could also be a reason for the different outcomes, along with the fact that the critically ill patients in the SGC group had longer ICU stays and might therefore have been in more need of care and rehabilitation. These differences between the intervention groups have to be regarded as a study limitation, making the outcomes hard to compare. Thus, differences in characteristics between the two groups may also provide a way of understanding the differences in the outcomes.

The results from one method were clarified against the results from another, and the range and breadth were extended using the most appropriate method for the multiple components. Validity was improved by investigating the convergence, corroboration, and correspondence of the results from the different methods.

It is important to understand which intervention has the best outcome for both patients and family members. However, finding the best ICU follow-up or mix of follow-up methods that best target the problem areas experienced by the family members/family will require more 
research. In order to provide the conditions for the family to be involved in the care of their loved one and maintain family function, the health care system should offer a more familyfocused form of care. 


\section{References}

Agren, S., Eriksson, A., Fredrikson, M., Hollman-Frisman, G., \& Orwelius, L. (2019). The health promoting conversations intervention for families with a critically ill relative: A pilot study. Intensive Crit Care Nurs, 50, 103-110. doi:10.1016/j.iccn.2018.04.007

Ahlberg, M., Backman, C., Jones, C., Walther, S., \& Hollman Frisman, G. (2015). Moving on in life after intensive care--partners' experience of group communication. Nursing Critical Care, 20(5), 256-263. doi:10.1111/nicc.12192

Ahlberg, M., Hollman Frisman, G., Bertero, C., \& Agren, S. (2020). Family Health Conversations create awareness of family functioning. Nursing Critical Care, 25(2), 102-108. doi:10.1111/nicc. 12454

Alfheim, H. B., Hofso, K., Smastuen, M. C., Toien, K., Rosseland, L. A., \& Rustoen, T. (2019). Post-traumatic stress symptoms in family caregivers of intensive care unit patients: A longitudinal study. Intensive Critical Care Nursing, 50, 5-10. doi:10.1016/j.iccn.2018.05.007

Altman, D. G. (1991). Practical statistics for medical research. London: Chapman and Hall.

Anderson, W. G., Arnold, R. M., Angus, D. C., \& Bryce, C. L. (2008). Posttraumatic stress and complicated grief in family members of patients in the intensive care unit. Journal of General Internal Medicine, 23(11), 1871-1876. doi:10.1007/s11606-008-0770-2

Antonovsky, A., \& Sourani, T. (1988). Family Sense of Coherence and Family Adaptation. Journal of Marriage and Family, 50(1), 79-92. doi:10.2307/352429

Astedt-Kurki, P., Paavilainen, E., \& Lehti, K. (2001). Methodological issues in interviewing families in family nursing research. The Journal of Advanced Nursing, 35(2), 288-293. doi:10.1046/j.1365-2648.2001.01845.x

Benzein, E., \& Berg, A. (2003). The Swedish version of the Herth Hope Index--an instrument for palliative care. Scandinavian Journal of Caring Sciences, 17(4), 409-415. doi:10.1046/j.0283-9318.2003.00247.x

Benzein, E. G., Hagberg, M., \& Saveman, B. I. (2008). 'Being appropriately unusual': a challenge for nurses in health-promoting conversations with families. Nursing Inquiry, 15(2), 106-115. doi:10.1111/j.1440-1800.2008.00401.x

Benzein, E., Olin, C., \& Persson, C. (2015). 'You put it all together' - families' evaluation of participating in Family Health Conversations. Scandinavian Journal of Caring Sciences, 29(1), 136-144. doi:10.1111/scs.12141

Bolosi, M., Peritogiannis, V., Tzimas, P., Margaritis, A., Milios, K., \& Rizos, D. V. (2018). Depressive and Anxiety Symptoms in Relatives of Intensive Care Unit Patients and the Perceived Need for Support. Journal of Neurosciences in Rural Practice, 9(4), 522-528. doi:10.4103/jnrp.jnrp_112_18

Bylund, A., Arestedt, K., Benzein, E., Thorell, A., \& Persson, C. (2016). Assessment of family functioning: evaluation of the General Functioning Scale in a Swedish Bariatric Sample. Scandinavian Journal of Caring Sciences, 30(3), 614-622. doi:10.1111/scs.12269

Creswell, J. W. (2014). Research design: qualitative, quantitative, and mixed methods approaches. Los Angeles, Calif.: SAGE.

Dorell, Å., Isaksson, U., Östlund, U., \& Sundin, K. (2017). Family Health Conversations have Positive Outcomes on Families - A Mixed Method Research Study. The Open Nursing Journal, 11, 14-25. doi:10.2174/1874434601711010014

Eggenberger, S. K., \& Nelms, T. P. (2007). Family interviews as a method for family research. Journal of Advanced Nursing, 58(3), 282-292. doi:10.1111/j.13652648.2007.04238.x 
Epstein, N. B., Baldwin, L. M., \& Bishop, D. S. (1983). THE McMASTER FAMILY ASSESSMENT DEVICE*. Journal of marital and family therapy, 9(2), 171-180. doi:10.1111/j.1752-0606.1983.tb01497.x

Fetters, M. D., Curry, L. A., \& Creswell, J. W. (2013). Achieving integration in mixed methods designs-principles and practices. Health Services Research, $48(6 \mathrm{Pt} 2), 2134-$ 2156. doi:10.1111/1475-6773.12117

Field, A. (2013). Discovering statistics using IBM SPSS statistics: and sex and drugs and rock ' $n$ ' roll. Los Angeles: Sage.

Greene, J. C., Caracelli, V. J., \& Graham, W. F. (1989). Toward a Conceptual Framework for Mixed-Method Evaluation Designs. Educational Evaluation and Policy Analysis, 11(3), 255-274. doi:10.3102/01623737011003255

Griffith DM, Salisbury LG, Lee RJ, Lone N, Merriweather JL, Walsh TS; RECOVER Investigators. (2018). Determinants of Health-Related Quality of Life After ICU: Importance of Patient Demographics, Previous Comorbidity, and Severity of Illness. Critical Care Medicine. 46(4):594-601. doi: 10.1097/CCM.0000000000002952. PMID: 29293149

Hays, R. D., \& Morales, L. S. (2001). The RAND-36 measure of health-related quality of life. Annals of Medicine, 33(5), 350-357. doi:10.3109/07853890109002089

Herth, K. (1992). Abbreviated instrument to measure hope: development and psychometric evaluation. Journal of Advanced Nursing, 17(10), 1251-1259. doi:10.1111/j.13652648.1992.tb01843.x

Heyland, D. K., Davidson, J., Skrobik, Y., des Ordons, A. R., Van Scoy, L. J., Day, A. G., . . Marshall, A. P. (2018). Improving partnerships with family members of ICU patients: study protocol for a randomized controlled trial. Trials, 19(1), 3. doi:10.1186/s13063017-2379-4

Jack, S. (2008). Guidelines to support nurse-researchers reflect on role conflict in qualitative interviewing. The Open Nursing Journal, 2, 58-62. doi:10.2174/1874434600802010058

Jonasdottir, R. J., Jones, C., Sigurdsson, G. H., \& Jonsdottir, H. (2018). Structured nurse-led follow-up for patients after discharge from the intensive care unit: Prospective quasiexperimental study. Journal of Advanced Nursing, 74(3), 709-723. doi:10.1111/jan.13485

Jonasdottir, R. J., Klinke, M. E., \& Jonsdottir, H. (2016). Integrative review of nurse-led follow-up after discharge from the ICU. Journal of Clinical Nursing, 25(1-2), 20-37. doi:10.1111/jocn.12939

Kallio, H., Pietilä, A. M., Johnson, M., \& Kangasniemi, M. (2016). Systematic methodological review: developing a framework for a qualitative semi-structured interview guide. Journal of Advanced Nursing, 72(12), 2954-2965. doi: 10.1111/jan.13031

Kirshbaum-Moriah, D., Harel, C., \& Benbenishty, J. (2018). Family members' experience of an intensive care unit support group: qualitative analysis of intervention. Nursing in Critical Care, 23(5), 256-262. doi:10.1111/nicc.12272

Kynoch, K., Chang, A., Coyer, F., \& McArdle, A. (2016). The effectiveness of interventions to meet family needs of critically ill patients in an adult intensive care unit: a systematic review update. JBI Database of Systematic Reviews and Implementation Reports, 14(3), 181-234. doi:10.11124/jbisrir-2016-2477

Lasiter, S., Oles, S. K., Mundell, J., London, S., \& Khan, B. (2016). Critical Care Follow-up Clinics: A Scoping Review of Interventions and Outcomes. Clinical Nurse Specialists, 30(4), 227-237. doi:10.1097/nur.0000000000000219 
Lieblich, A., Tuval-Mashiach, R., \& Zilber, T. (1998). Narrative research: reading, analysis, and interpretation. Thousand Oaks, Calif.: Sage.

Mollerberg, M. L., Arestedt, K., Sandgren, A., Benzein, E., \& Swahnberg, K. (2020). Adaptation and psychometric evaluation of the short version of Family Sense of Coherence Scale in a sample of persons with cancer in the palliative stage and their family members. Palliative \& Supportive Care, 18(1), 24-32. doi:10.1017/s1478951519000592

Nelson, L. P., Lachman, S. E., Li, S. W., \& Gold, J. I. (2019). The Effects of Family Functioning on the Development of Posttraumatic Stress in Children and Their Parents Following Admission to the PICU. Pediatric Critical Care Medicine, 20(4), e208e215. doi:10.1097/pcc.0000000000001894

Orwelius L, Kristenson M, Fredrikson M, Walther S, Sjöberg F.(2017a) Hopelessness: Independent associations with health-related quality of life and short-term mortality after critical illness: A prospective, multicentre trial. Journal of Critical Care. 41:5863. doi: 10.1016/j.jcrc.2017.04.044. Epub 2017 Apr 28. PMID: 28482237

Orwelius, L., Nilsson, M., Nilsson, E., Wenemark, M., Walfridsson, U., Lundstrom, M., . . . Kristenson, M. (2017b). The Swedish RAND-36 Health Survey - reliability and responsiveness assessed in patient populations using Svensson's method for paired ordinal data. The Journal of Patient-Reported Outcomes, 2(1), 4. doi:10.1186/s41687018-0030-0

Peskett, M., \& Gibb, P. (2009). Developing and setting up a patient and relatives intensive care support group. Nursing in Critical Care, 14(1), 4-10. doi:10.1111/j.14785153.2008.00302.x

Regulation (EU) 2016/679 of the European Parliament and of the Council of 27 April 2016 on the protection of natural persons with regard to the processing of personal data and on the free movement of such data, and repealing Directive 95/46/EC(General Data Protection Regulation) (Text with EEA relevance). Retrieved from http://data.europa.eu/eli/reg/2016/679/oj

Rosa, R. G., Ferreira, G. E., Viola, T. W., Robinson, C. C., Kochhann, R., Berto, P. P., . . Teixeira, C. (2019). Effects of post-ICU follow-up on subject outcomes: A systematic review and meta-analysis. Journal of Critical Care, 52, 115-125. doi:10.1016/j.jcrc.2019.04.014

Schofield-Robinson, O. J., Lewis, S. R., Smith, A. F., McPeake, J., \& Alderson, P. (2018). Follow-up services for improving long-term outcomes in intensive care unit (ICU) survivors. Cochrane database of systematic reviews, 11, Cd012701. doi:10.1002/14651858.CD012701.pub2

SIR. (2020). The Swedish Intensive Care Registry. Retrieved from http://www.icuregswe.org/sv/Om-SIR/

Stewart, A. L., \& Ware, J. E. (1992). Measuring functioning and well-being: the medical outcomes study approach: Duke University Press.

Sundin, K., Bäckström, B., Lindh, V., Lindkvist, M., Saveman, B.-I., \& Östlund, U. (2016). Responses after participating in family health conversations in families with a family member who has suffered a stroke: A mixed methods research study. Clinical Nursing Studies, 4(4), 46-57. doi: 10.5430/cns.v4n4p46

Tashakkori, A., \& Teddlie, C. (2010). Sage handbook of mixed methods in social \& behavioral research. Thousand Oaks: SAGE Publications.

The World Medical Association, (2013). Declaration of Helsinki. Medical Research Involving Human Subjects. Retrieved from https://www.wma.net/policies-post/wma_declarationof-helsinki-ethical-principles-for-medical-research-involving human-subjects/ 
van Beusekom, I., Bakhshi-Raiez, F., de Keizer, N. F., Dongelmans, D. A., \& van der Schaaf, M. (2016). Reported burden on informal caregivers of ICU survivors: a literature review. Critical Care, 20, 16. doi:10.1186/s13054-016-1185-9

Vandall-Walker, V., \& Clark, A. M. (2011). It starts with access! A grounded theory of family members working to get through critical illness. Journal of Family Nursing, 17(2), 148-181. doi:10.1177/1074840711406728

Verhaeghe, S. T., van Zuuren, F. J., Defloor, T., Duijnstee, M. S., \& Grypdonck, M. H. (2007). The process and the meaning of hope for family members of traumatic coma patients in intensive care. Qualitative Health Research, 17(6), 730-743. doi:10.1177/1049732307303242

Whall, A. L. (1986). The family as the unit of care in nursing: a historical review. Public Health Nursing, 3(4), 240-249. doi:10.1111/j.1525-1446.1986.tb00495.x

Wright, L. M., \& Bell, J. M. (2009). Beliefs and illness: a model for healing. [Calgary]: 4th Floor Press.

Wright, L. M., \& Leahey, M. (2013). Nurses and families: a guide to family assessment and intervention. Philadelphia: F.A. Davis.

Östlund, U., Bäckström, B., Saveman, B.-I., Lindh, V., \& Sundin, K. (2016). A family systems nursing approach for families following a stroke: Family health conversations. Journal of Family Nursing, 22(2), 148-171.doi: 10.1177/1074840716642790 
Table 1. Characteristics of family members in the FamHC (patients excluded) and family members in the SGC.

\begin{tabular}{|l|c|c|c|c|}
\hline & $\begin{array}{c}\text { FamHC } \\
\text { (family members } \\
\text { - patient, } \mathrm{n=10)}\end{array}$ & $\begin{array}{c}\text { SGC } \\
\text { family members, } \\
\mathrm{n}=21)\end{array}$ & p-value & $\begin{array}{c}\text { The Fisher } \\
\text { exact test }\end{array}$ \\
\hline Age, years (mean \pm SD) & $53 \pm 18$ & $59 \pm 14$ & .357 & \\
\hline Female gender, $\mathrm{n}(\%)$ & $7(78)$ & $12(57)$ & .299 & 0.419 \\
\hline Employment, $\mathbf{n}(\%)$ & & & .247 & 0.427 \\
\hline Full time/part time & $3(33)$ & $12(57)$ & $\mathrm{ns}$ & \\
\hline Pension/disability pension/sick leave & $6(67)$ & $9(43)$ & $\mathrm{ns}$ & \\
\hline Number of groups & 7 & 7 & $\mathrm{~ns}$ & \\
\hline Mean stay in the ICU for the patient in days & 8 & 13 &. $\mathbf{0 2 8}$ & \\
\hline Numbers of families participating & 7 & 13 & & \\
\hline
\end{tabular}


Table 2. Comparison within and between the two intervention groups from baseline to 3 months. The numbers (No) are full scored questioners that are taken in account for the analysis.

\begin{tabular}{|c|c|c|c|c|c|c|c|c|c|c|c|}
\hline & & FamHC & & & & & & SGC & & & $\begin{array}{l}\text { FamHC } \\
\text { vs SGC }\end{array}$ \\
\hline $\begin{array}{l}\text { Questioners } \\
\text { and } \\
\text { dimensions }\end{array}$ & & $\begin{array}{l}\text { Mean } \\
\text { (SD) }\end{array}$ & No & $\begin{array}{l}\text { Mean } \\
\text { (SD) } \\
\text {-patient }\end{array}$ & $\begin{array}{l}\text { No } \\
\text { - patient }\end{array}$ & $p$-Value & & $\begin{array}{l}\text { Mean } \\
\text { (SD) }\end{array}$ & No & $\begin{array}{l}\mathrm{p}- \\
\text { Value }\end{array}$ & $p$-Value \\
\hline GFS & $\begin{array}{l}\text { Baseline } \\
\text { 3-months }\end{array}$ & $\begin{array}{l}1.7(0.6) \\
1.5(0.5)\end{array}$ & $\begin{array}{l}16 \\
14\end{array}$ & $\begin{array}{l}1.9(0.8) \\
1.6(0.6)\end{array}$ & $\begin{array}{l}8 \\
7\end{array}$ & $\begin{array}{l}.042 * / \\
.144 * *\end{array}$ & $\begin{array}{l}\text { Baseline } \\
\text { 3-months }\end{array}$ & $\begin{array}{l}1.7(0.6) \\
2.8(0.5)\end{array}$ & $\begin{array}{l}21 \\
19\end{array}$ & .000 & $.001 * * *$ \\
\hline FSOC-S & $\begin{array}{l}\text { Baseline } \\
\text { 3-months }\end{array}$ & $\begin{array}{l}39.6(8.7) \\
38.8(11.7)\end{array}$ & $\begin{array}{l}17 \\
14\end{array}$ & $\begin{array}{l}41.2(3.6) \\
43.9(3)\end{array}$ & $\begin{array}{l}8 \\
7\end{array}$ & $\begin{array}{l}.298 * / \\
.709 * *\end{array}$ & $\begin{array}{l}\text { Baseline } \\
\text { 3-months }\end{array}$ & $\begin{array}{l}41.1(2.2) \\
46.9(1.8)\end{array}$ & $\begin{array}{l}21 \\
19\end{array}$ & .001 & $.066 * * *$ \\
\hline $\begin{array}{l}\text { Comprehens } \\
\text { ability }\end{array}$ & $\begin{array}{l}\text { Baseline } \\
\text { 3-months }\end{array}$ & $\begin{array}{l}16.3(5.1) \\
15.3(4.5)\end{array}$ & $\begin{array}{l}17 \\
14\end{array}$ & $\begin{array}{l}16.9(6.1) \\
17.6(5)\end{array}$ & $\begin{array}{l}8 \\
7\end{array}$ & $\begin{array}{l}.330 * / \\
.895 * *\end{array}$ & $\begin{array}{l}\text { Baseline } \\
\text { 3-months }\end{array}$ & $\begin{array}{l}17.7(4.7) \\
18.7(4.2)\end{array}$ & $\begin{array}{l}21 \\
19\end{array}$ & .033 & $.217 * * *$ \\
\hline $\begin{array}{l}\text { Manage } \\
\text { ability }\end{array}$ & $\begin{array}{l}\text { Baseline } \\
\text { 3-months }\end{array}$ & $\begin{array}{l}11.7(2.2) \\
10.9(1.9)\end{array}$ & $\begin{array}{l}17 \\
14\end{array}$ & $\begin{array}{l}12(2.1) \\
12.1(1.9)\end{array}$ & $\begin{array}{l}8 \\
7\end{array}$ & $\begin{array}{l}.183 * / \\
.576 * *\end{array}$ & $\begin{array}{l}\text { Baseline } \\
\text { 3-months }\end{array}$ & $\begin{array}{l}10.9(1.4) \\
10.7(1.9)\end{array}$ & $\begin{array}{l}21 \\
19\end{array}$ & .895 & $.821 * * *$ \\
\hline $\begin{array}{l}\text { Meaning } \\
\text { fulness }\end{array}$ & $\begin{array}{l}\text { Baseline } \\
\text { 3-months }\end{array}$ & $\begin{array}{l}13.2(5.6) \\
12.6(6.6)\end{array}$ & $\begin{array}{l}17 \\
14\end{array}$ & $\begin{array}{l}14.3(6.9) \\
17.5(6.1)\end{array}$ & $\begin{array}{l}9 \\
7\end{array}$ & $\begin{array}{l}.739 * / \\
.703 * *\end{array}$ & $\begin{array}{l}\text { Baseline } \\
\text { 3-months }\end{array}$ & $\begin{array}{l}13.4(5.3) \\
14.1(2.5)\end{array}$ & $\begin{array}{l}21 \\
19\end{array}$ & .001 & $.066 * * *$ \\
\hline $\mathrm{HHI}$ & $\begin{array}{l}\text { Baseline } \\
\text { 3-months }\end{array}$ & $\begin{array}{l}40.7(4.2) \\
41.5(5.5)\end{array}$ & $\begin{array}{l}17 \\
14\end{array}$ & $\begin{array}{l}41.1(4.4) \\
42.6(5.7)\end{array}$ & $\begin{array}{l}9 \\
7\end{array}$ & $\begin{array}{l}.076 / \\
.071 *\end{array}$ & $\begin{array}{l}\text { Baseline } \\
\text { 3-months }\end{array}$ & $\begin{array}{l}38.5(6.4) \\
34.1(2.6)\end{array}$ & $\begin{array}{l}21 \\
19\end{array}$ & .002 & $.016 * * *$ \\
\hline SF36/RAND & & & & & & & & & & & \\
\hline $\begin{array}{l}\text { PF physical } \\
\text { function }\end{array}$ & $\begin{array}{l}\text { Baseline } \\
\text { 3-months }\end{array}$ & $\begin{array}{l}67.9(32.7) \\
73.2(25.2)\end{array}$ & $\begin{array}{l}17 \\
14\end{array}$ & $\begin{array}{l}88.2(12.2) \\
78.6(26.4)\end{array}$ & $\begin{array}{l}9 \\
7\end{array}$ & $\begin{array}{l}.703 * / \\
.258 * * \\
\end{array}$ & $\begin{array}{l}\text { Baseline } \\
\text { 3-months }\end{array}$ & $\begin{array}{l}75.5(22.3) \\
53.9(17.2)\end{array}$ & $\begin{array}{l}19 \\
19\end{array}$ & .006 & $.599 * * *$ \\
\hline $\begin{array}{l}\text { RF role } \\
\text { function }\end{array}$ & $\begin{array}{l}\text { Baseline } \\
\text { 3-months }\end{array}$ & $\begin{array}{l}55.6(44.4) \\
55.4(46.2)\end{array}$ & $\begin{array}{l}17 \\
14\end{array}$ & $\begin{array}{l}61.1(48.6) \\
64.3(47.6)\end{array}$ & $\begin{array}{l}9 \\
7\end{array}$ & $\begin{array}{l}.605 \% / \\
1.00 * *\end{array}$ & $\begin{array}{l}\text { Baseline } \\
\text { 3-months }\end{array}$ & $\begin{array}{l}76.3(36.8) \\
75.5(22.4)\end{array}$ & $\begin{array}{l}19 \\
19\end{array}$ & .888 & $.375^{* * *}$ \\
\hline $\begin{array}{l}\text { BP body } \\
\text { pain }\end{array}$ & $\begin{array}{l}\text { Baseline } \\
\text { 3-months }\end{array}$ & $\begin{array}{l}59.2(27.6) \\
64.5(29.6)\end{array}$ & $\begin{array}{l}17 \\
14\end{array}$ & $\begin{array}{l}65.1(25.3) \\
61.6(28.7)\end{array}$ & $\begin{array}{l}8 \\
7\end{array}$ & $\begin{array}{l}.835 * / \\
.398 * *\end{array}$ & $\begin{array}{l}\text { Baseline } \\
\text { 3-months }\end{array}$ & $\begin{array}{l}75.1(21.2) \\
76.3(36.8)\end{array}$ & $\begin{array}{l}18 \\
19\end{array}$ & .419 & $.073 * * *$ \\
\hline $\begin{array}{l}\text { GH general } \\
\text { health }\end{array}$ & $\begin{array}{l}\text { Baseline } \\
\text { 3-months }\end{array}$ & $\begin{array}{l}61.9(20.9) \\
66.9(21.7)\end{array}$ & $\begin{array}{l}17 \\
14\end{array}$ & $\begin{array}{l}64.7(21.4) \\
75.1(21.2)\end{array}$ & $\begin{array}{l}9 \\
7\end{array}$ & $\begin{array}{l}.357 * / \\
.504 * *\end{array}$ & $\begin{array}{l}\text { Baseline } \\
\text { 3-months }\end{array}$ & $\begin{array}{l}66.7(19.8) \\
69.6(21.3)\end{array}$ & $\begin{array}{l}18 \\
18\end{array}$ & .141 & $.779 * * *$ \\
\hline VT vitality & $\begin{array}{l}\text { Baseline } \\
\text { 3-months }\end{array}$ & $\begin{array}{l}57.1(24.4) \\
65.7(22.2)\end{array}$ & $\begin{array}{l}17 \\
14\end{array}$ & $\begin{array}{l}56.7(28.6) \\
66.4(22.7)\end{array}$ & $\begin{array}{l}9 \\
7\end{array}$ & $\begin{array}{l}.160 * / \\
.180 * *\end{array}$ & $\begin{array}{l}\text { Baseline } \\
\text { 3-months }\end{array}$ & $\begin{array}{l}53.6(21.5) \\
66.7(19.8)\end{array}$ & $\begin{array}{l}18 \\
18\end{array}$ & .012 & $.505^{* * *}$ \\
\hline $\begin{array}{l}\text { SF social } \\
\text { function }\end{array}$ & $\begin{array}{l}\text { Baseline } \\
\text { 3-months }\end{array}$ & $\begin{array}{l}61.8(30.8) \\
81.2(27.2)\end{array}$ & $\begin{array}{l}17 \\
14\end{array}$ & $\begin{array}{l}68.1(36) \\
80.4(33)\end{array}$ & $\begin{array}{l}9 \\
7\end{array}$ & $\begin{array}{l}.049 * / \\
.466 * *\end{array}$ & $\begin{array}{l}\text { Baseline } \\
\text { 3-months }\end{array}$ & $\begin{array}{l}69.4(29.8) \\
53.6(21.5)\end{array}$ & $\begin{array}{l}18 \\
18\end{array}$ & .001 & $.110 * * *$ \\
\hline $\begin{array}{l}\text { RE role } \\
\text { functioning }\end{array}$ & $\begin{array}{l}\text { Baseline } \\
\text { 3-months }\end{array}$ & $\begin{array}{l}64.7(39.9) \\
76.2(33.1)\end{array}$ & $\begin{array}{l}17 \\
14\end{array}$ & $\begin{array}{l}77.8(33.3) \\
85.7(26.2)\end{array}$ & $\begin{array}{l}9 \\
7\end{array}$ & $\begin{array}{l}.533 * / \\
.766 * *\end{array}$ & $\begin{array}{l}\text { Baseline } \\
\text { 3-months }\end{array}$ & $\begin{array}{l}70.4(39.4) \\
69.4(29.8)\end{array}$ & $\begin{array}{l}18 \\
18\end{array}$ & .882 & $.337 * * *$ \\
\hline $\begin{array}{l}\text { MH mental } \\
\text { health }\end{array}$ & $\begin{array}{l}\text { Baseline } \\
\text { 3-months }\end{array}$ & $\begin{array}{l}75.3(15.2) \\
85.1(11.1)\end{array}$ & $\begin{array}{l}17 \\
14\end{array}$ & $\begin{array}{l}72.9(16.8) \\
81.7(13.8)\end{array}$ & $\begin{array}{l}9 \\
7\end{array}$ & $\begin{array}{l}.040 * / \\
.185 * *\end{array}$ & $\begin{array}{l}\text { Baseline } \\
\text { 3-months }\end{array}$ & $\begin{array}{l}70.7(20.1) \\
70.4(39.4)\end{array}$ & $\begin{array}{l}18 \\
18\end{array}$ & .963 & $.584 * * *$ \\
\hline
\end{tabular}

No= Number of completed questionnaires

*p-value for comparison within group, mean over time; 3 months - baseline

**p-value for comparison within group, mean over time; 3 months - baseline without patient in the FamHC intervention.

***p-value for comparison between groups, mean over time, with 10 logarithm value between the two groups; 3 months - baseline,

without patient in the FamHC intervention. 


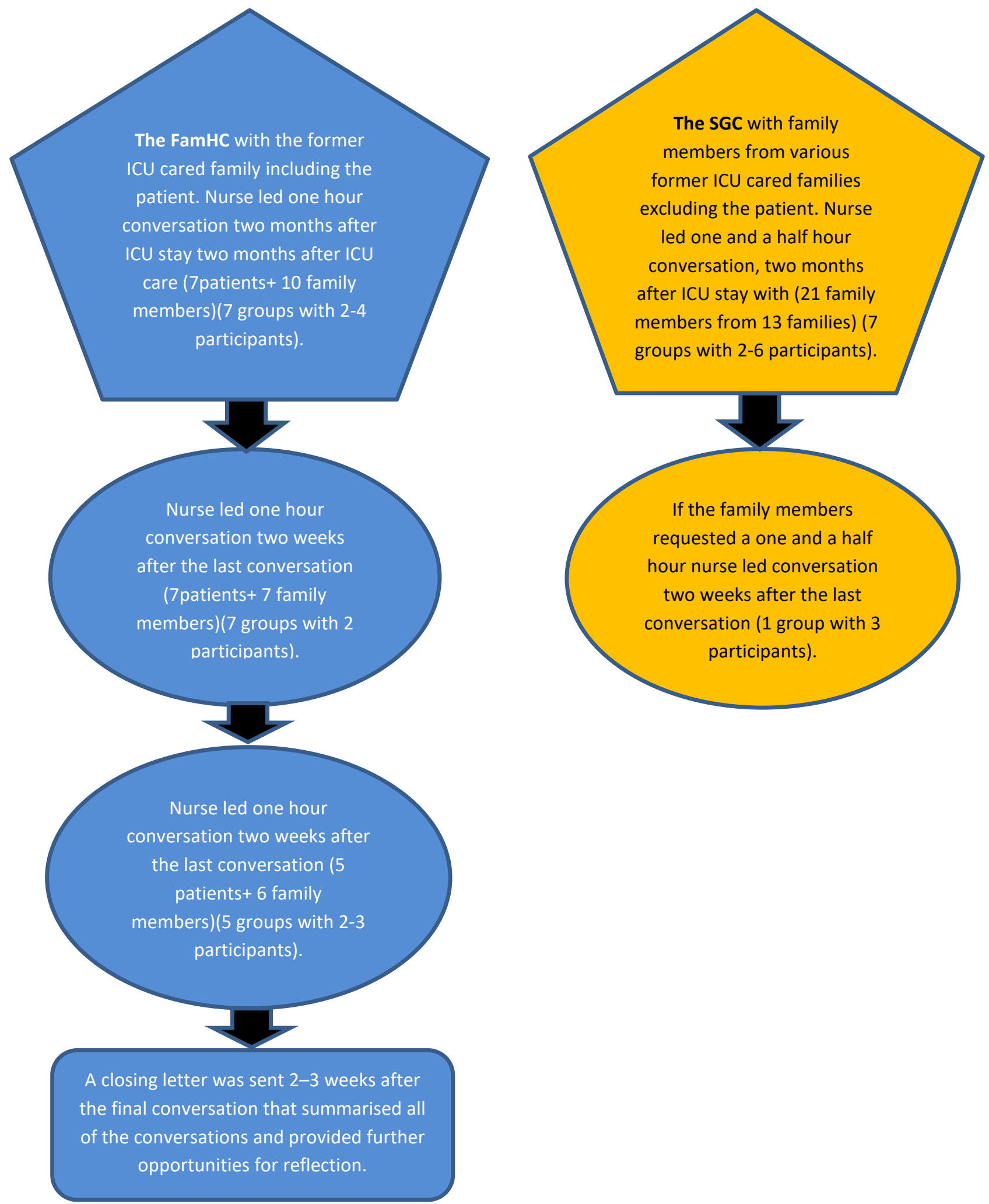

Figure 1. A flowchart showing the two interventions FamHC and SGC. 


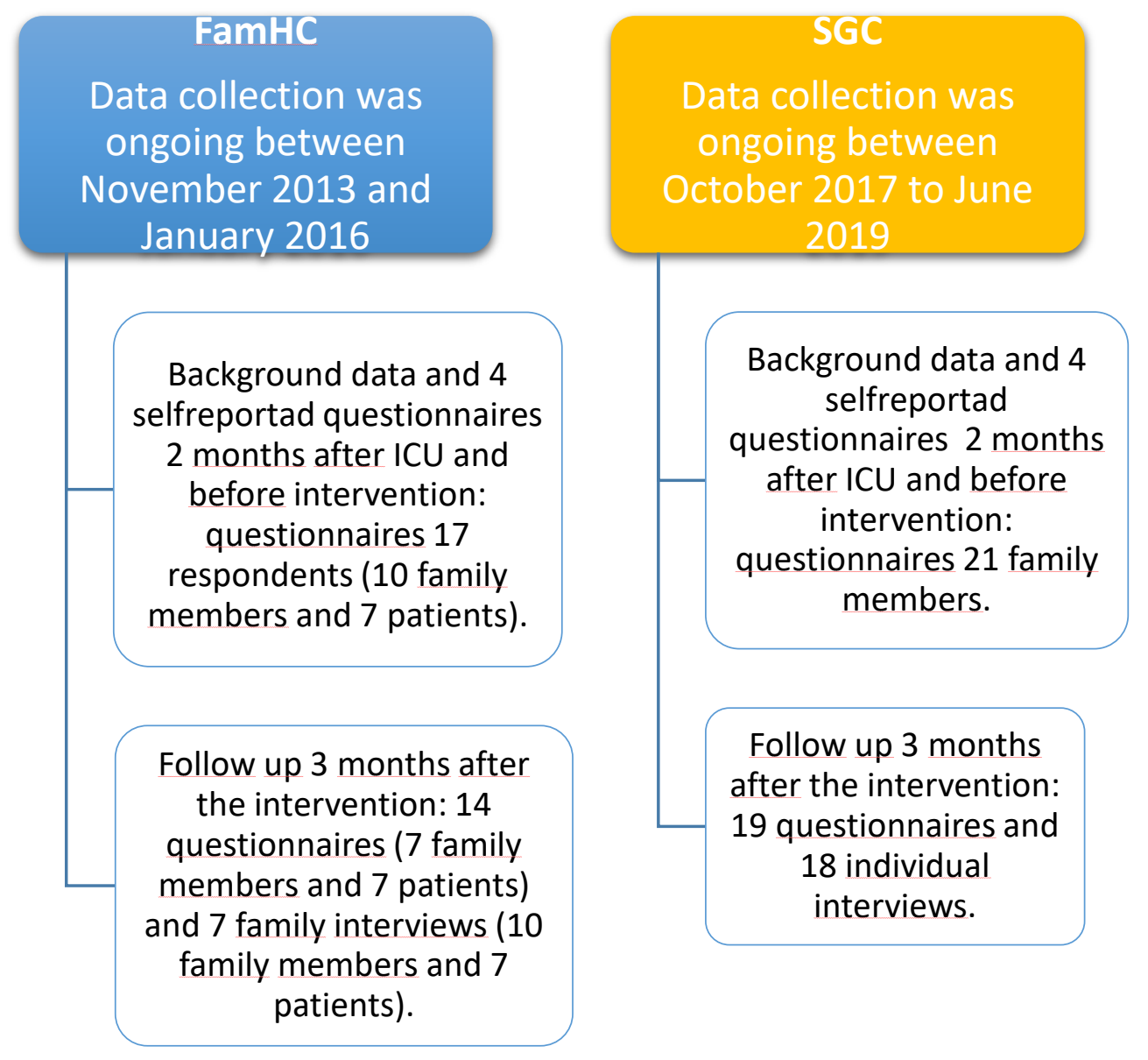

Figure 2. Data collection process and number of respondents. 


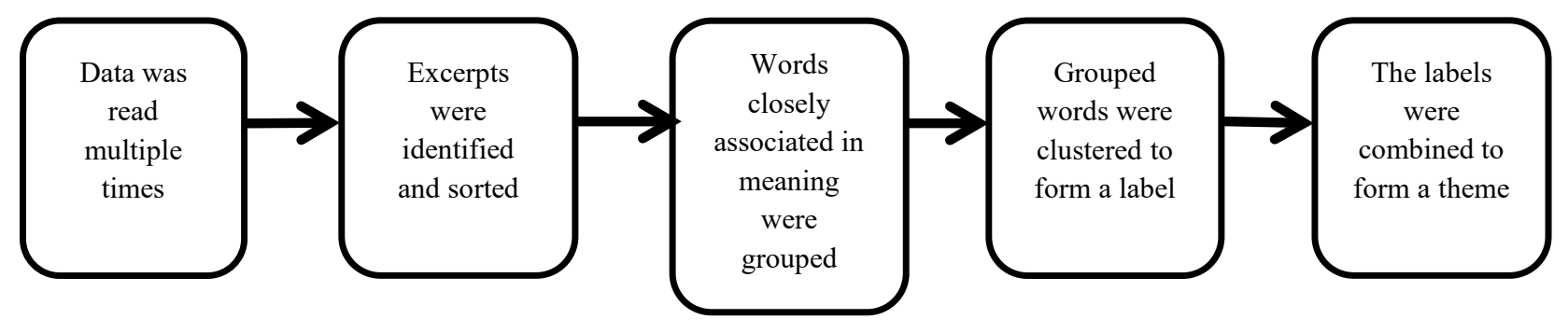

Figure 3. Narrative Analytical Process 


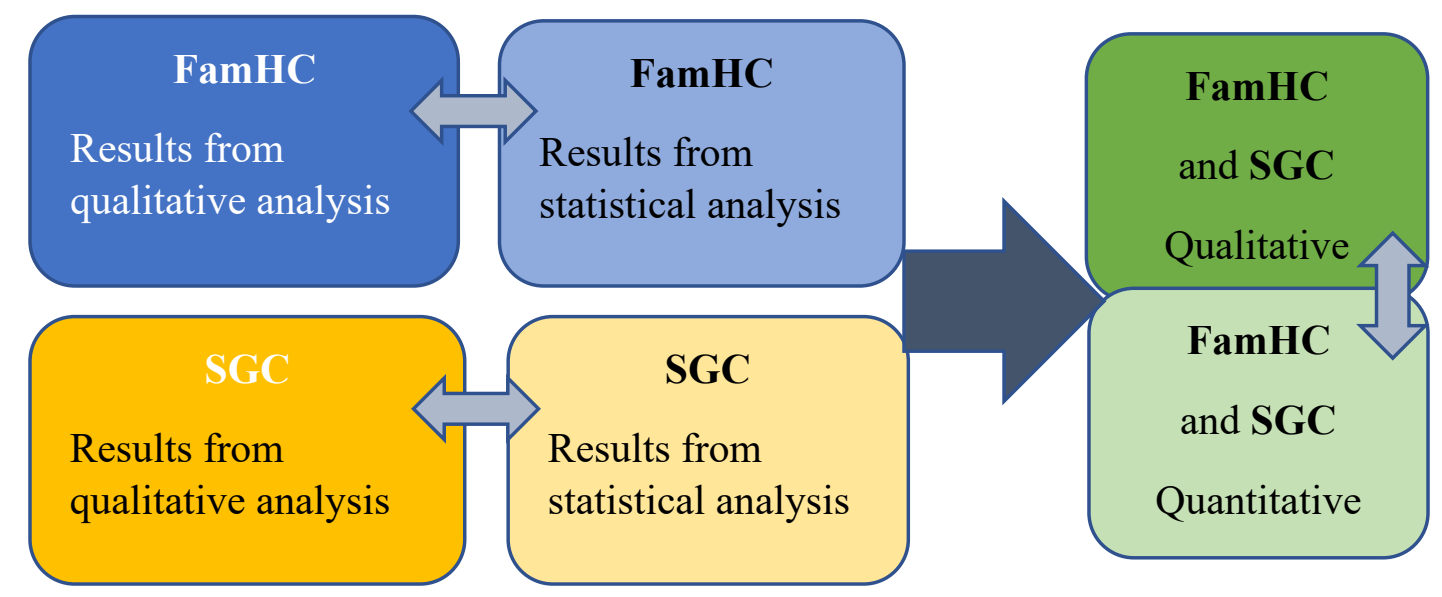

Figure 4. The process of mixed method analysis, showing the triangulation within and between FamHC and SGC. 